PR-12

\title{
METHOD DEVELOPMENT AND VALIDATION OF A REVERSED PHASE HPLC METHOD FOR DETERMINATION OF ANASTRAZOLE AND TEMOZOLOMIDE IN PHARMACEUTICAL DOSAGE FORM
}

\author{
N. MD. Akram, ${ }^{*}$ N. Madana Gopal, ${ }^{2}$ A. Balakrishna, ${ }^{3}$ N. Bakthavatchala Reddy ${ }^{4}$ \\ ${ }^{1}$ Santhiram Engineering College, Nandyal, Kurnool (Dt), Andhra Pradesh. India. \\ ${ }^{2}$ Santhiram College of pharmacy, Nandyal, Kurnool(Dt), Andhra Pradesh. India. \\ ${ }^{3}$ Rajeev Gandhi Memorial College of Engineering and Technology (Autonomous), Nandyal \\ 518501, Andhra Pradesh, India. \\ ${ }^{4}$ Ural Federal University, Chemical Engineering Institute, \\ Yekaterinburg, 620002, Russian Federation. \\ *Corresponding author, E-mail: mdakram.chem@gmail.com
}

\begin{abstract}
A new simple assay method has been developed and validated for the determination of Anastrazole and Temozolomide using reverse-phase high performance liquid chromatography in their pharmaceutical dosage form. The chromatographic separation was performed on an Inertsil ODS (4.6 $\mathrm{x}$ $150 \mathrm{~mm}, 5 \mu \mathrm{m}$ ) using mobile phase phosphate buffer $\mathrm{pH} 3.0$ and methanol of 30:70\% v/v at a flow rate of $0.8 \mathrm{~mL} / \mathrm{min}$. Analytes were detected at $260 \mathrm{~nm}$. The method was found to be linear in the concentration range of $1-5 \mu \mathrm{g} / \mathrm{mL}$ for both medicaments with the coefficient value (R2) of $>0.999$. The accuracy was measured via recovery studies and found to be acceptable and the percentage recoveries were found in the range of 98.81-100.72 and 99.29-100.70\%. The proposed method was successfully validated and applied for the quantitative estimation of these drugs in both bulk and tablet dosage forms.
\end{abstract}

